\title{
電力系統における負荷の電圧特性の算出と推定
}

\author{
正 員 山 益 功 (北陸電力) \\ 正 員 金 尾 則 一 (北陸電力) \\ 正員 柳 田 孫 肖 (北陸電力)
}

\section{Calculation and Estimation of Load Voltage Characteristics in Power System}

Mitsunori Yamashita, Member, Norikazu Kanao, Member, Hikoni Yanagida, Member, (Hokuriku Electric Power Company)

\begin{abstract}
This paper presents a method for calculating and estimating the parameters of a bus load model in power system stability studies. There are two basic approaches to obtain load voltage characteristics. One is to directly measure the voltage sensitivity of load active power and reactive power at substations or feeders. The other is to build up a composite load model from knowledge of the mix of load class. It is effective to calculate load voltage characteristics by utilizing the feature of both approaches.

The bus load model we propose consists of a load branch with equivalent impedance to the feeders and transformers in the $66 \mathrm{kV}$ or $77 \mathrm{kV}$ distribution system, reactive power compensation and load, which is composed of three load classes, such as industrial, commercial and residential. The load voltage characteristics are calculated from voltage and current measured at several feeders, where voltage sag due to a fault occurs. The static load voltage characteristics are represented the exponents, and have correlation with temperature. Exponents of load class are calculated from the measured exponents, temperature and load class mix by least-squares method. The validity to be applicable for the estimated exponents by the exponents of load class and the mix of load classes is evaluated. The bus load using this exponents will be adaptable to not-measured bus loads. They will make stability simulation results more accurate.
\end{abstract}

キーワード：負荷電圧特性，負荷ブランチ，無効電力補償，気温，電力種別構成，最小二乗法

Keywords : load voltage characteristics, load branch, reactive power compensation, temperature, load class mix, least squares method

\section{1. まえがき}

電力設備の計画・運用において効率的，安定な電力供給 のためには，発電機，送電線，負荷などを精度良く模擬し た電力系統解析が重要である。特に，負荷特性は発電機や 送電線などと違い，需要家におうける無数の負荷機器 (load device; 照明器具, 冷藏庫, 空調機器など) の構成比および 使用状態が変化するため，そのもデリングや定数算出には 困難な面がある(1)。

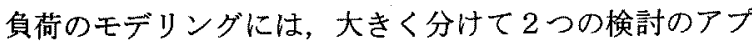
ローチがある(2)〜(4)。一つは, 負荷機器の単体特性を理論的 解析や実験室での実測により把握し(5)，これらがある構成比 で組み合わされたものとする構成ベース方式 (componentbased method), も5一つは, 変電所や送電線におりる有効 電力および無効電力を電圧の感度として負荷特性を直接実 测し求める ${ }^{(6)}$ 実测ベース方式（measurement-based method）である。構成ベース方式は，変電所や送電線での 実測が不要である利点があるが，個々の変電所や送電線に おける負荷機器の構成比を決定することが困難である欠点 がある。一方，実測ベース方式は，実測した特定の変電所 や送電線の負荷特性を電力系統解析に直接適用できる利点 があるが，他地点の負荷特性として適用できるとは言い難 い。このため，実測ベース方式で得られた負荷特性の実測 值から，他地点の負荷特性を推定できるような負荷特性の 一般式を求めることが望ましい。このような考えから，計 測データの各次高調波の值をもとに負荷機器の構成比を求 め，負荷特性を同定する方法(7)などの検討が行われている が，実系統への適用には検討の余地が多いと思われる。 そこで，実測，構成ベースの両方式の特徴を活かす観点 から, 負荷電圧特性の一つの要素である電圧静特性定数（以 下，電圧静特性）の推定方法について，図 1 に示す手順に より検討を行ったので報告する。 


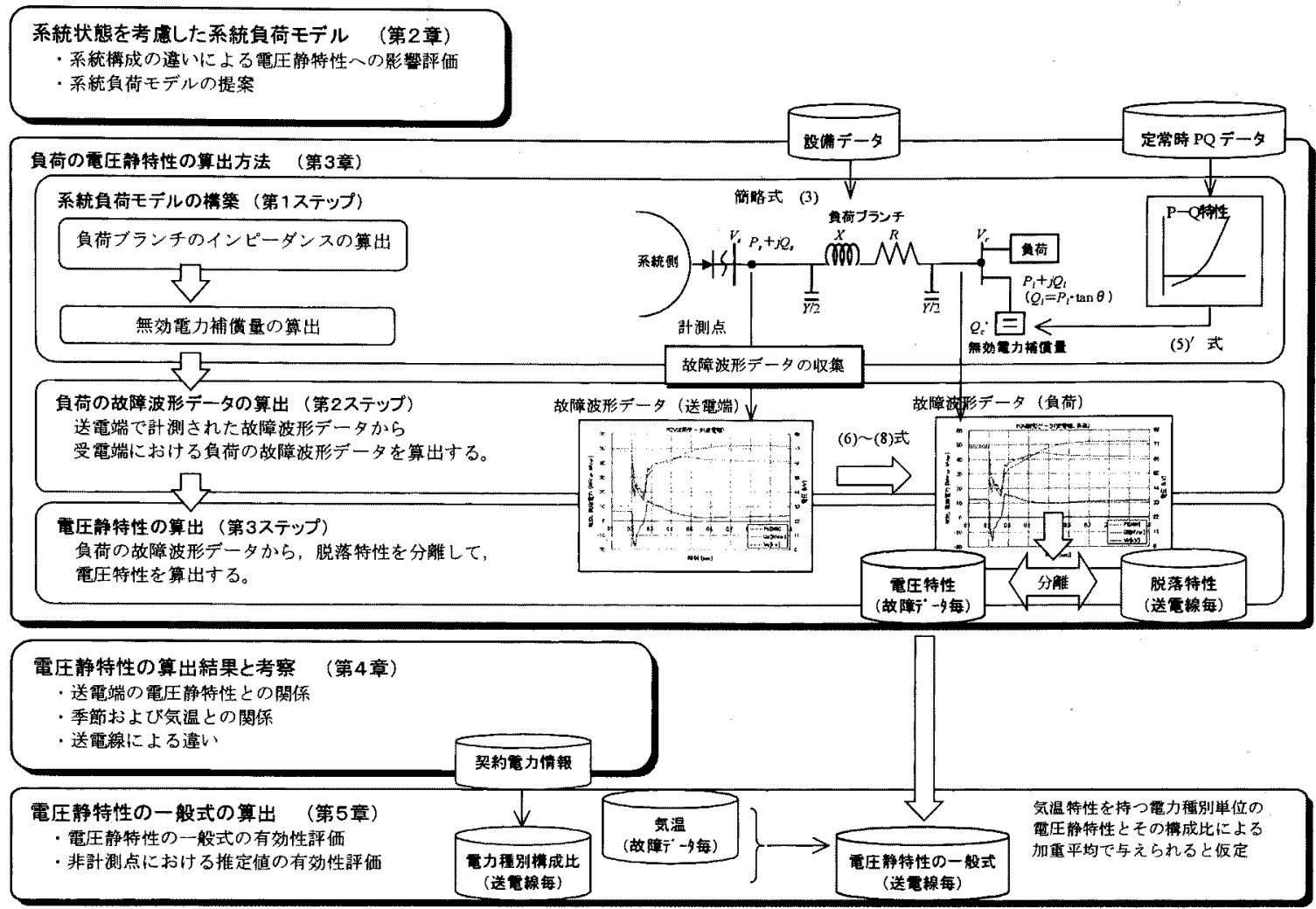

電力系統解析への適用方法 (第6章)

・系統鱼荷モデルと電圧静特性の推定值の電力系統解析への適用方法

図 1 電圧静特性の分析概要

Fig. 1. Overview of analysis of load voltage characteristics.

まず，第 2 章では，基幹系の電力系統解析で使用する連 系用変電所二次側（本論文では， $66 ， 77 \mathrm{kV}$ ）の負荷として, 負荷系統内の電力損失を考慮した系統負荷モデルを提案す る。第 3 章では,この負荷の電圧静特性の算出方法を示し, 第 4 章では，実測デー夕を用いた電圧静特性の算出結果と 気温との相関などについて述べる。次に第 5 章では，この 負荷が電力種別 (load class; 工業, 商業, 住宅) で構成さ れるものと考え，最小二乗法を用いて気温特性を持つ電力 種別単位の電圧静特性を求め, 負荷の電圧静特性をその構 成比から一般的に表現する方法を提案し（以下，電圧静特 性の一般式，，その有效性を評価する。最後に第 6 章で，提 案する系統負荷モデルと電圧静特性の推定値の電力系統解 析への適用方法を示す。

\section{2. 系統状態を考慮した系統負荷モデル}

基幹系の電力系統解析では, 図 $2(\mathrm{a})$ に示す連系用変電所 二次側の負荷系統をどのように簡略化して表現するかが課 題となる。従来から提案されている系統負荷モデル(8)では， 図 2 (b)に示すようにコンデンサと負荷から構成され，負荷 系統内の電力損失は負荷の一部に含めているものが多い。 このため，計测点である送電端で算出される負荷特性は， 系統棈成の影響を受けることになる(9)。リアクタンス
$X$ [p.u.]（ここでは抵抗 $R[$ p.u.]，アドミタンス $Y$ [p.u.]は零と 仮定），負荷の大きさ $W_{l}\left(=P_{l}+j Q_{l}\right)$ [p.u.]おうよひ負荷の電圧 静特性 $K p r ， K q r((1) ，(2)$ 式参照) を用いて，送電端の電圧 静特性 $K p s, K q s$ を求め, 系統構成の違いによる電圧静特性 八の影響を，送受電端の電圧静特性の比 $K p s / K p r, K q s / K q r$ で図3に示した。

$$
\begin{aligned}
& P_{l}=P_{l i} \cdot\left(\frac{V_{r}}{V_{r i}}\right)^{K p r} \\
& Q_{i}=Q_{l i} \cdot\left(\frac{V_{r}}{V_{r i}}\right)^{K p r}
\end{aligned}
$$

添穴字 $i$ は初期值を示す。

$V_{r}:$ 受電端電圧 [p.u.]

$P_{l}, Q_{l}:$ 負荷の有効, 無効電力 [p.u.]

$K p r, K q r$ : 有効, 無効電力の電圧静特性

これより $X, W_{l}$ が大きいほど影響が大きく，比率の大小 は Kpr，Kqrの組合せによって決まることがわかる。また， この比率が Kps より Kqs の方が大きいは，リアクタンス における無効電力損失のためである（付録 1 ）。なお，Kpr， $K q r$ がともに定インピーダンス特性 $(K p r=K q r=2)$ であれば， $X, W_{l}$ によらず $K p s=K q s=2$ であり, $K p r$ が定電力特性 $(K p r=0)$ 


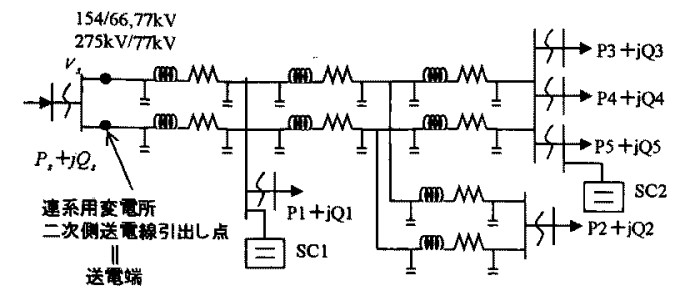

（a）負荷系縄のメーシ

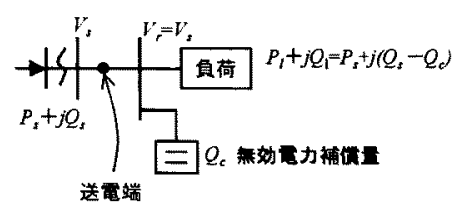

（b）従来の系統角荷モデル

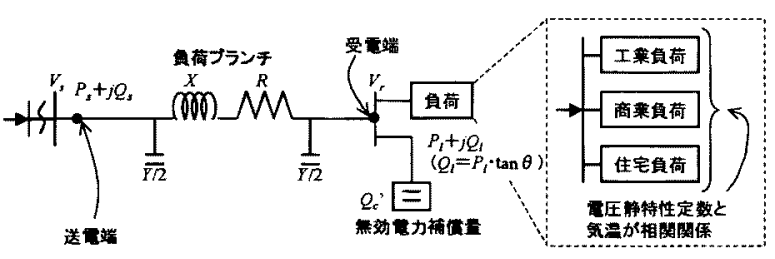

（c）提案する系統負荷モデル

魚荷系統：送電線引出し点からみた下位系統

系統負荷モデル：負荷機器を含さ負荷系統全体のモデル

負荷ブランチ：負荷采統相当のインビーダンスを模擬したブランチ

図 2 系統負荷モデル

Fig. 2. Bus load model.

であれば， $X, W_{l}$ によらず $K p s=0(K q r, K q s$ も同様）とな る。

このように, 送電端の電圧静特性は, 負荷系統で異なる インピーダンスや潮流状態の影響を受けることから，電圧 静特性を一般的に求めるには，負荷系統を図 2 (c)に示寸よ うな系統負荷モデルで表現し，受電端に接続される負荷の 電圧静特性を求めることが必要になる。

\section{3. 負荷の電圧静特性の算出方法}

〈3.1〉概要 提案する系統負荷モデル（図 2 (c)) に おける負荷の電圧静特性を求めるため，図 1 のように，次 の3つのステップにより行う。

第 1ステップ：系統負荷モデルを構成する負荷ブランチ, 無効電力補償量の値を求める。負荷ブランチのインピーダ ソスは設備データから, 無効電力補償量は定常時の送電端 有効電力と無効電力データをプロットした $\mathrm{P}-\mathrm{Q}$ 特性から 求める。

第 2 ステップ: 負荷の電圧静特性を求めるには, 負荷の $P_{l}$ $+j Q_{l}$ と電圧 $V_{r}$ の電圧変化時の時系列データが必要である。 本論文では，系統故障による瞬時電圧低下時の故障波形デ
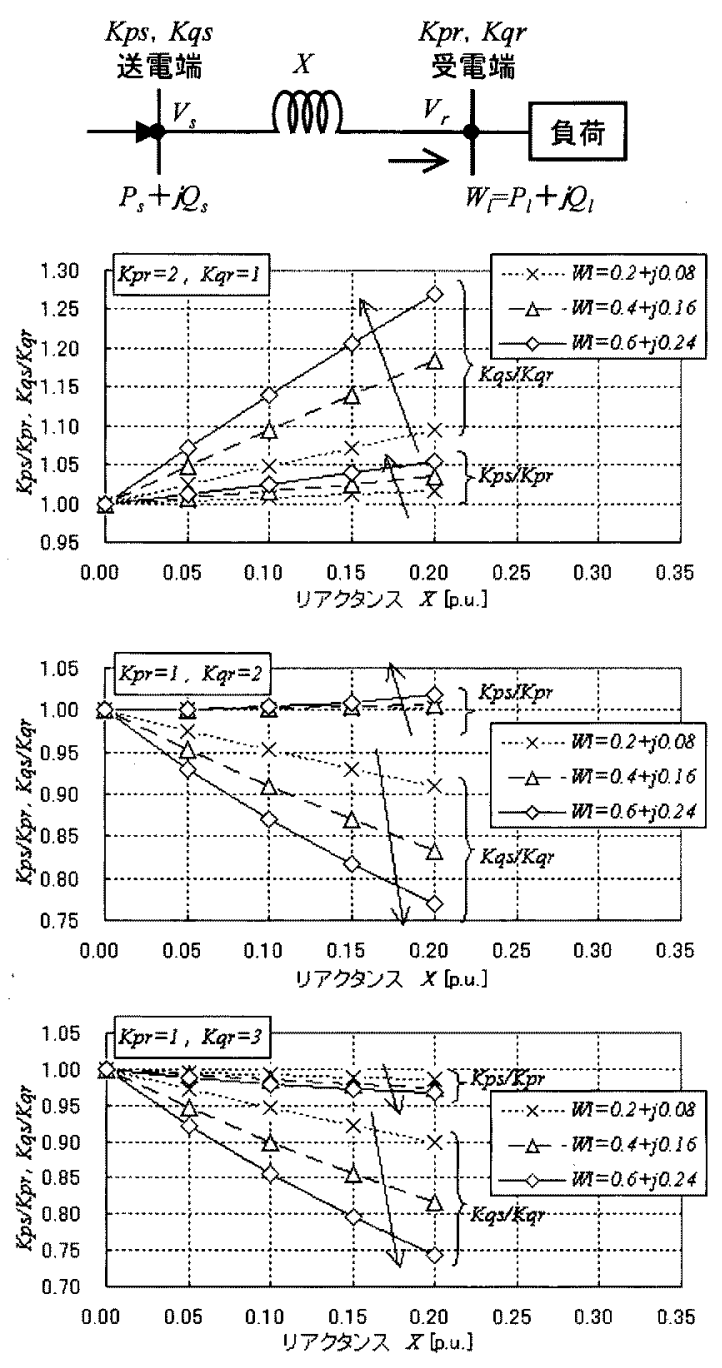

図 3 送電端と負荷の電圧静特性比

Fig. 3. Ratio of the exponent at feeder sending end to the exponent at load.

ータを利用することとした。計測される故障波形データは 送電端潮流 $P_{s}+j Q_{s}$ と電圧 $V_{s}$ であるため, これを第 1 ステッ プで求めた系統負荷モデルに与え，負荷の $P_{l}+j Q_{l}$ と電圧 $V_{r}$ の故障波形データを求める。

第 3ステップ: 負荷の $P_{l}+j Q_{l}$ と電庄 $V_{r}$ の故障波形データか ら, 負荷の脱落特性を分離して, 電圧静特性 $K p r, K q r$ を求 め。

\section{$\langle 3 \cdot 2\rangle \quad$ 系統負荷モデルの楧築}

$\langle 3 \cdot 2 \cdot 1\rangle$ 負荷プランチのインピーダンスの算出 負 荷ブランチのリアクタンス $X[\mathrm{p} . \mathrm{u}$.]は，第 2 章の検討から負 荷系統の無効電力損失を保存寸るよ5に求める。なお， 66 , $77 \mathrm{kV}$ 負荷系統の検討であることから，負荷ブランチの抵抗 $R$ [p.u.]，アドミタンス $Y$ [p.u.]は十分小さく零として扱う。

無効電力損失を保存する $X$ を求めるには, 負荷系統の詳 細潮流計算を行えばよいが，計算が煩雑なことから現実的 でない。このため, 負荷系統内の設備データのみから算出

電学論 B，122 巻 12 号，平成 14 年 
できる簡略式(3)を考案した。ここでは,リアクタンスは送 電線に比べ変圧器が支配的であり, 負荷は変圧器容量比率 で供給されると仮定した。

$$
X=\frac{\sum_{i}^{m_{T R}} W_{T R i}^{2} \cdot X_{T R i}}{\left(\sum_{i}^{m_{T R}} W_{T R i}\right)^{2}}
$$

$W_{T R i}:$ 変圧器容量 [p.u.]

$X_{T R j}:$ 変圧器リアクタンス [p.u.]

$m_{T R}:$ 変圧器総数

（3）式による簡略算出の妥当性を評価するため，A1，A3 線（A 変電所におりる 2 つの引出し点）について詳細潮流 計算から求まる(4)式のリアクタンス $X_{0}$ [p.u.]と比較した。図 4 に負荷系統の一例を示す。なお, 詳細な負荷の分布比率 は潮流断面により異なると考えられることから，夏期ピー ク, 年間平均, GWナイトの実績潮流断面, さらに変圧器 容量比率で配分した仮想潮流断面において検愔を行った。

$$
X_{0}=\frac{V_{s}^{2} \cdot \sum_{i}^{m_{S R}} Q_{\text {lassi }}}{P_{s}^{2}+Q_{s}^{2}} .
$$

$V_{s}:$ 送電端の電圧 $[$ p.u. $]$

$Q_{\text {loss }}:$ 各ブランチの無効電力損失 [p.u.]

$P_{s}, Q_{s}:$ 送電端の有効, 無効電力 [p.u.]

$m_{B R}:$ ブランチ総数

表 1 に検討結果を示す。これより， $X_{0}$ は潮流断面によっ て值が異なるものの， $X$ はこの範囲内にあることから，(3） 式の算出方法は概衫妥当と判断できる。また，容量比率断 面の $X_{0}$ が $X$ より大きいのは送電線のリアクタンスでの無効 電力損失も考虑しているためであり，この差はわずかであ ることから変圧器のリアクタンスが支配的であることが確 認できる。

表 1 負荷ブランチのリアタタンス

\begin{tabular}{|c|c|c|c|c|}
\hline 送電線 & $X$ [p.u.] & 潮流断面 & $P_{s}$ [p.u.] & $X_{0}$ [p.u. $]$ \\
\hline \multirow[t]{4}{*}{ Al } & \multirow[t]{4}{*}{0.14} & 夏期ピーク & 0.845 & 0.15 \\
\hline & & 年間平均 & 0.490 & 0.15 \\
\hline & & GWナイト & 0.283 & 0.14 \\
\hline & & 容量比率 & 0.500 & 0.15 \\
\hline \multirow[t]{4}{*}{ A3 } & \multirow[t]{4}{*}{0.10} & 夏期ビーク & 0.730 & 0.12 \\
\hline & & 年間平均 & 0.390 & 0.10 \\
\hline & & GWナイト & 0.181 & 0.11 \\
\hline & & 容量比率 & 0.500 & 0.11 \\
\hline
\end{tabular}

Table 1. Reactance of load branch.

100MVA ベース值

各負荷は $Q_{l}=0.4^{*} P_{l}$ と仮定し，配変，特高需要家変圧器二次貸に設定

$\langle 3 \cdot 2 \cdot 2\rangle$ 效電力補償量の算出 故障直前の負荷系 統内の無効電力補償量 $Q_{c}{ }^{\prime}$ [p.u.]を故障波形データのみから 求めることは困難であるため，次の方法で算出する。

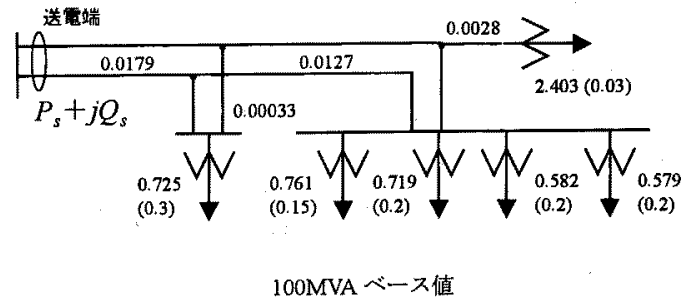

值 [p.u.] はリアクタンス, 変压器容䁷（カッコ内）を示す。 2 回線䇢所位 1 回線值

図 4 負荷系統の設備データ（例：A1 線）

Fig. 4. Reactance and MVA of feeders and transformers.

定常時データ（毎正時の電圧電流データ）から求まる送 電端有効電力 $P_{s 0}[\mathrm{p} . \mathrm{u}$.$] と無効電力 Q_{s 0}[\mathrm{p} . \mathrm{u}$.$] をプロットする$ と, 図 5 に示寸 $\mathrm{P}-\mathrm{Q}$ 特性が得られる(1)(6)(8)。図 $2(\mathrm{c})$ の系統 負荷モデル（R，Yは零として扱う）において $\tan \theta$ （負荷 $\left.の Q_{l} / P_{l}\right)$ 定と仮定した場合, 送電端の $\mathbf{P}-\mathbf{Q}$ 特性は (5) 式で表されることから，定常時データから $\tan \theta$ と $Q_{c}$ [p.u.] を最小二乗法で求めておく。 $Q_{c}$ は常時負荷系統内に接続さ れているコンデンサなどの平均的な無効電力補償量であ る。なお，負荷系統内におけるコンデンサの開閉や系統変更 により $\mathrm{P}-\mathrm{Q}$ 特性が複数の群となる場合がある。今回の分析 ではコンデンサの開閉による群は考慮するが，系統変更に よる群は採用しないこととした。

$$
\begin{aligned}
& Q_{s 0}=\frac{X \cdot\left(P_{s 0}^{2}+Q_{s 0}^{2}\right)}{V_{s 0}^{2}}+(\tan \theta) \cdot P_{l 0}+Q_{c} \cdot\left(\frac{V_{r 0}}{V_{c}}\right)^{2} \cdots \cdots \cdots(5) \\
& こ こ て ゙, \quad V_{r 0}=\sqrt{\left(V_{s 0}-\frac{X \cdot Q_{s 0}}{V_{s 0}}\right)^{2}+\left(\frac{X \cdot P_{s 0}}{V_{s 0}}\right)^{2}}, \quad P_{l 0}=P_{s 0}
\end{aligned}
$$

$P_{t 0}$ : 負荷の有効電力（定常時） [p.u.]

$V_{c}:$ 無効電力補償量の定格電圧 (1 [p.u.])

$V_{r 0}:$ 受電端電圧（定常時） [p.u.]

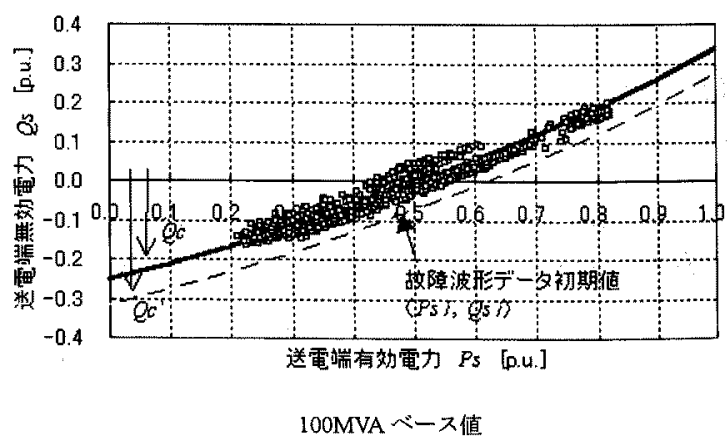

図 $5 \mathrm{P}-\mathrm{Q}$ 特性（例：A1 線）

Fig. 5. Characteristics of active power and reactive power.

T. IEE Japan, Vol. 122-B, No.12, 2002 
故障直前の無効電力補償量 $Q_{c}{ }^{\prime} は, \tan \theta$ と故障波形デー 夕から読み取れる故障直前の送電端潮流 $P_{s i}+j Q_{s i}[\mathrm{p} . \mathrm{u}$.$] 電$ 圧 $V_{s i}[\mathrm{p} . \mathrm{u}$.$] を用いて，(5)'式より Q_{c}$ を補正して求める。

$$
\begin{aligned}
& Q_{s}{ }^{\prime}=\left(\frac{V_{c}}{V_{n}}\right)^{2} \cdot\left\{Q_{s i}-\frac{X \cdot\left(P_{s i}^{2}+Q_{s i}^{2}\right)}{V_{s i}^{2}}-(\tan \theta) \cdot P_{l i}\right\} \cdots \cdots \cdot(5) \\
& こ こ て ゙, \quad V_{r i}=\sqrt{\left(V_{s i}-\frac{X \cdot Q_{s i}}{V_{s i}}\right)^{2}+\left(\frac{X \cdot P_{s i}}{V_{s i}}\right)^{2}}, \quad P_{l i}=P_{s i}
\end{aligned}
$$

〈3.3〉負荷の故障波形データの算出 瞬時電生低下 時の故障波形デ一夕から求まる送電端潮流 $P_{s}+j Q_{s}[\mathrm{p} . \mathrm{u}$.] 電圧 $V_{s}$ [p.u.]用いて，(6)，(7)，(8)式により時系列に算出 することで，負荷の $P_{l}+j Q_{l}$ [p.u.]，電圧 $V_{r}[$ [p.u.]の故障波形 データを求めることができる。図6に一例を示す。

$$
\begin{aligned}
& V_{r}=\sqrt{\left(V_{s}-\frac{X \cdot Q_{s}}{V_{s}}\right)^{2}+\left(\frac{X \cdot P_{s}}{V_{s}}\right)^{2}} \\
& P_{1}=P_{s} \\
& Q_{1}=Q_{s}-\frac{X \cdot\left(P_{s}^{2}+Q_{s}^{2}\right)}{V_{s}^{2}}-Q_{c}^{\prime} \cdot\left(\frac{V_{r}}{V_{c}}\right)^{2}
\end{aligned}
$$

$V_{r}:$ 受電端の電压（故障時） [p.u.]

$P_{l}, Q_{l}$ : 負荷の有効, 無効電力（故障時） [p.u.]

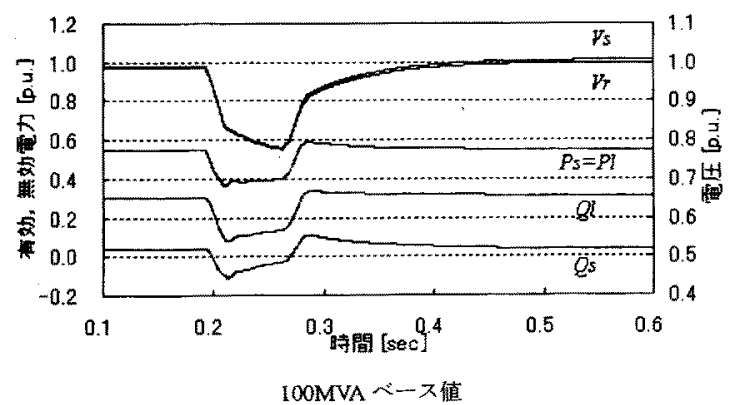

図 6 送電端と負荷の故障波形データ（例：A1 線）

Fig. 6. Variation of voltage, active power and reactive power.

〈3.4〉電圧静特性の算出 故障時の電圧低下の大き さにより負荷脱落が起こるため，故障除去後に負荷が落ち 着いた值 $P_{l}, Q_{l}[\mathrm{p} . \mathrm{u}$.$] には, 負荷脱落と電圧静特性の影響が$ 重疊される。この様相を図 7 に示す。

このため，ます収集した故障波形デ一タを送電線，季節

(夏期，夏期以外）毎に分類して平均的脱落特性を算出吉 る。次に各故障波形データについて負荷脱落量を求め, 分 離した後，電圧静特性 $K p r ， K q r$ を算出する(10)。なお，平均 的脱落特性は折線モデル（付録 2）を，電圧特性は伝達関 数で表現した動特性そデル(9)，（10)式を採用した。

$$
P_{l}=P_{l i} \cdot\left\{\frac{1}{1+T p \cdot s} \cdot\left(\frac{V_{r}}{V_{n}}\right)^{K p r}+\frac{T p \cdot s}{1+T p \cdot s} \cdot\left(\frac{V_{r}}{V_{n}}\right)^{K_{p r}}\right\} \cdots
$$

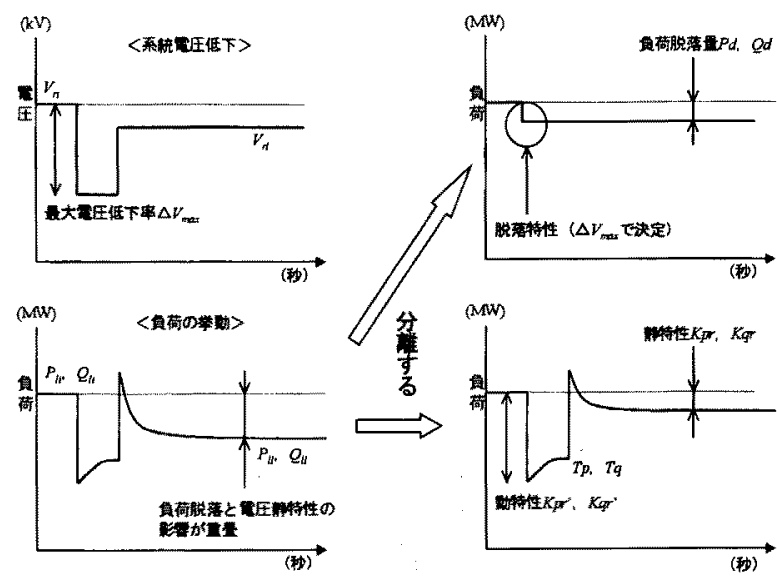

図 7 負荷脱落と電圧静特性の影響の分離

Fig. 7. Separation between the discontinuous load and the static load.

$$
Q_{i}=Q_{i i} \cdot\left\{\frac{1}{1+T q \cdot s} \cdot\left(\frac{V_{r}}{V_{r i}}\right)^{K_{q r}}+\frac{T q \cdot s}{1+T q \cdot s} \cdot\left(\frac{V_{r}}{V_{r i}}\right)^{K_{q r^{\prime}}}\right\} \ldots
$$

$K p r, K q r$ : 有効, 無効電力の電圧静特性

$K p r^{\prime}, T p$ : 有効電力の電圧動特性定数, 時定数 $K q r^{\prime}, T q$ : 無効電力の電圧動特性定数, 時定数

\section{4. 電圧静特性の算出結果と考察}

〈4-1〉電圧静特性の算出結果 第 3 章の算出方法に より，次の寒測データから電圧静特性を算出した。表 2 に 送電端における電压静特性 $K p s, K q s(X=0$ で算出）の平均 值と分散, 負荷の電圧静特性 $K p r, K q r$ の平均值と分散の算 出結果，お゙よび平均的脱落特性， $X, \tan \theta$ を示す。なお，故 障波形データについては，30 分以内の連続故障などは不採 用とした。

・定常時データ；

毎正時に計測したデータ

1 送電線あたり 936 件（8 週分）

・故障波形データ;

故障発生時に計測したデータ

サンプリング周波数 $3840 \mathrm{~Hz}$

計測時閒 $1 \sim 2$ 秒

（故障継続時間などにより、データ長が異なる） 5 変電所 $(A \sim E)$, 合計 11 送電線引き出し点 採用データ数 全 539 件（1996/10～2001/9）

$\langle 4 \cdot 2\rangle$

考察

$\langle 4 \cdot 2 \cdot 1\rangle \quad$ 送電端の電圧静特性との関係 表 2 より送 電端における Kps，Kqsは，これまでの報告例(1)と大差ない。 負荷の K pr は Kps とほぼ同じであるが，負荷の Kqr は Kqs に比べ全体的に大きな值となった。

〈4・2・2〉季節およひ気温との関係 表 2 より夏期の $K p r, K q r$ は, 夏期以外の $K p r, K q r$ に比べ小さな值となっ 


\section{表 2 電圧静特性の算出結果と各諸量}

Table. 2. Exponents of voltage, load ramp down parameters, equivalent reactance, load power factor and rate of load class mix.

\begin{tabular}{|c|c|c|c|c|c|c|c|c|c|c|c|c|c|c|}
\hline \multirow[t]{2}{*}{ 遥電線 } & \multirow{2}{*}{$\begin{array}{l}\text { 用デ } \\
- \text { 夕数 }\end{array}$} & \multicolumn{2}{|c|}{ 选電端们電圧静特性 } & \multicolumn{2}{|c|}{ 負荷の電任静特性 } & \multirow{2}{*}{ 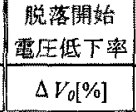 } & \multirow{2}{*}{ 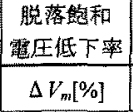 } & \multicolumn{2}{|c|}{ 脱落墦加率 } & \multirow{2}{*}{$\begin{array}{c}X \\
\text { [p.u.] } \\
\end{array}$} & \multirow{2}{*}{$\begin{array}{l}\tan \theta \\
\left(Q / P_{l}\right)\end{array}$} & \multicolumn{3}{|c|}{ 電力種別權成比 } \\
\hline & & Kps（有効） & $K q s$ (無效) & $\mathrm{Kpr}$ (献知) & Kqr (無效) & & & Ap (有効) & $A q($ 烸効) & & & $P_{1}($ 工策 $)$ & $P_{2}$ (商業) & $P_{1}$ (住宅) \\
\hline Al & $\begin{array}{l}16 \\
27 \\
\end{array}$ & $\begin{array}{l}0.76(0.038) \\
1.16(0.016)\end{array}$ & $\begin{array}{l}1.93(0.472) \\
2.74(0.175)\end{array}$ & $\begin{array}{l}0.76(0.046) \\
1.18(0.018)\end{array}$ & $\begin{array}{l}2.32(0.457) \\
3.23(0.257)\end{array}$ & $\begin{array}{l}14.9 \\
15.6\end{array}$ & $\begin{array}{l}51.2 \\
59.9\end{array}$ & $\begin{array}{l}0.49 \\
0.49\end{array}$ & $\begin{array}{l}0.81 \\
0.80\end{array}$ & 0.14 & 0.41 & 0.247 & 0.083 & 0.670 \\
\hline $\mathrm{A} 2$ & $\begin{array}{l}10 \\
19 \\
\end{array}$ & $\begin{array}{l}0.74(0.020) \\
1.02(0.017) \\
\end{array}$ & $\begin{array}{l}2.69(0.664) \\
3.45(0.609) \\
\end{array}$ & $\begin{array}{l}0.76(0.021) \\
1.04(0.023)\end{array}$ & $\begin{array}{l}3.28(0.852) \\
4.19(1.369) \\
\end{array}$ & $\begin{array}{l}11.5 \\
10.6\end{array}$ & $\begin{array}{l}48.7 \\
64.7\end{array}$ & $\begin{array}{l}0.53 \\
0.53\end{array}$ & $\begin{array}{l}0.91 \\
0.91\end{array}$ & 0.13 & 0.41 & 0.420 & 0.140 & 0.440 \\
\hline $\mathrm{A} 3$ & $\begin{array}{l}15 \\
19 \\
\end{array}$ & $\begin{array}{l}0.85(0.040) \\
1.17(0.017)\end{array}$ & $\begin{array}{l}2.77(0.401) \\
4.00(0.935) \\
\end{array}$ & \begin{tabular}{|l|}
$0.85(0.038)$ \\
$1.21(0.017)$ \\
\end{tabular} & $\begin{array}{l}3.59(0.424) \\
4.63(1.178) \\
\end{array}$ & $\begin{array}{l}9.3 \\
7.4\end{array}$ & $\begin{array}{l}73.5 \\
57.8 \\
\end{array}$ & $\begin{array}{l}0.45 \\
0.44\end{array}$ & $\begin{array}{l}0.71 \\
0.76 \\
\end{array}$ & 0.10 & 0.25 & 0.189 & 0.234 & 0.577 \\
\hline $\mathrm{Bl}$ & $\begin{array}{l}17 \\
27 \\
\end{array}$ & $\begin{array}{l}0.76(0.026) \\
1.10(0.024)\end{array}$ & $\begin{array}{l}2.25(0.352) \\
3.00(0.334) \\
\end{array}$ & $\begin{array}{l}0.77(0.028) \\
1.10(0.030)\end{array}$ & $\begin{array}{l}2.55(0.489) \\
3.46(0.481)\end{array}$ & $\begin{array}{l}13.0 \\
13.0\end{array}$ & $\begin{array}{l}54.3 \\
55.4\end{array}$ & $\begin{array}{l}0.82 \\
0.72\end{array}$ & $\begin{array}{l}1.45 \\
1.07\end{array}$ & 0.08 & 0.43 & 0.397 & 0.100 & 0.503 \\
\hline $\mathrm{B} 2$ & $\begin{array}{l}18 \\
31 \\
\end{array}$ & $\begin{array}{l}0.85(0.018) \\
1.15(0.017) \\
\end{array}$ & $\begin{array}{l}2.40(0.126) \\
2.79(0.249)\end{array}$ & $\begin{array}{l}0.86(0.019) \\
1.16(0.023) \\
\end{array}$ & $\begin{array}{l}2.82(0.199) \\
3.25(0.488)\end{array}$ & $\begin{array}{l}14.6 \\
16.1\end{array}$ & $\begin{array}{l}41.9 \\
53.3\end{array}$ & $\begin{array}{l}0.62 \\
0.63\end{array}$ & $\begin{array}{l}1.21 \\
1.21\end{array}$ & 0.11 & 0.42 & 0.277 & 0.119 & 0.604 \\
\hline B3 & $\begin{array}{l}17 \\
25 \\
\end{array}$ & $\begin{array}{l}0.74(0.055) \\
1.04(0.035)\end{array}$ & $\begin{array}{l}2.20(0.414) \\
2.95(0.613) \\
\end{array}$ & $\begin{array}{l}0.74(0.059) \\
1.05(0.039)\end{array}$ & $\begin{array}{l}2.52(0.614) \\
3.47(0.958) \\
\end{array}$ & $\begin{array}{l}12.1 \\
14.6 \\
\end{array}$ & $\begin{array}{r}56.3 \\
41.8 \\
\end{array}$ & $\begin{array}{l}0.86 \\
0.50 \\
\end{array}$ & $\begin{array}{l}1.46 \\
1.43 \\
\end{array}$ & 0.19 & 0.41 & 0.455 & 0.060 & 0.485 \\
\hline $\mathrm{C} 1$ & $\begin{array}{l}25 \\
26 \\
\end{array}$ & $\begin{array}{l}0.86(0.049) \\
1.16(0.029) \\
\end{array}$ & $\begin{array}{l}2.34(0.419) \\
2.81(0.152)\end{array}$ & $\begin{array}{l}0.88(0.052) \\
1.20(0.032)\end{array}$ & $\begin{array}{l}3.07(0.973) \\
3.36(0.298) \\
\end{array}$ & $\begin{array}{r}8.4 \\
9.7 \\
\end{array}$ & $\begin{array}{l}39.6 \\
71.9 \\
\end{array}$ & $\begin{array}{l}0.23 \\
0.25 \\
\end{array}$ & $\begin{array}{l}0.59 \\
0.41 \\
\end{array}$ & 0.16 & 0.46 & 0.233 & 0.154 & 0.613 \\
\hline $\mathrm{C} 2$ & $\begin{array}{l}20 \\
24 \\
\end{array}$ & $\begin{array}{l}0.92(0.030) \\
1.08(0.032) \\
\end{array}$ & $\begin{array}{l}2.36(0.339) \\
3.00(0.529) \\
\end{array}$ & $\begin{array}{l}0.92(0.033) \\
1.04(0.048) \\
\end{array}$ & $\begin{array}{l}2.63(0.407) \\
3.16(0.870) \\
\end{array}$ & $\begin{array}{l}10.9 \\
10.0 \\
\end{array}$ & $\begin{array}{l}43.5 \\
76.8 \\
\end{array}$ & $\begin{array}{l}0.65 \\
0.79 \\
\end{array}$ & $\begin{array}{l}1.75 \\
1.47 \\
\end{array}$ & 0.06 & 0.52 & 0.608 & 0.057 & 0.335 \\
\hline D1 & $\begin{array}{l}24 \\
49 \\
\end{array}$ & $\begin{array}{l}0.87(0.065) \\
1.15(0.055) \\
\end{array}$ & $\begin{array}{l}2.17(0.372) \\
2.65(0.372) \\
\end{array}$ & $\begin{array}{l}0.86(0.068) \\
1.17(0.059)\end{array}$ & $\begin{array}{l}2.60(0.425) \\
3.02(0.646)\end{array}$ & $\begin{array}{c}7.7 \\
10.1 \\
\end{array}$ & $\begin{array}{l}53.2 \\
89.0 \\
\end{array}$ & $\begin{array}{l}0.23 \\
0.24 \\
\end{array}$ & $\begin{array}{l}0.31 \\
0.51 \\
\end{array}$ & 0.75 & 0.31 & 0.138 & 0.075 & 0.787 \\
\hline $\mathrm{D} 2$ & $\begin{array}{l}28 \\
63 \\
\end{array}$ & $\begin{array}{l}0.84(0.075) \\
1.24(0.028)\end{array}$ & $\begin{array}{l}2.15(0.439) \\
2.59(0.220) \\
\end{array}$ & $\begin{array}{l}0.84(0.080) \\
1.24(0.036) \\
\end{array}$ & $\begin{array}{l}2.54(0.567) \\
2.95(0.393) \\
\end{array}$ & $\begin{array}{c}8.6 \\
12.7 \\
\end{array}$ & $\begin{array}{l}60.4 \\
77.6 \\
\end{array}$ & $\begin{array}{l}0.21 \\
0.20\end{array}$ & $\begin{array}{l}0.20 \\
0.35 \\
\end{array}$ & 0.39 & 0.38 & 0.080 & 0.127 & 0.793 \\
\hline E1 & $\begin{array}{l}15 \\
24\end{array}$ & $\begin{array}{l}0.70(0.020) \\
1.05(0.023)\end{array}$ & $\begin{array}{l}1.99(0.448) \\
3.09(0.322)\end{array}$ & $\begin{array}{l}0.70(0.021) \\
1.06(0.025)\end{array}$ & $\begin{array}{l}2.31(0.510) \\
3.60(0.657)\end{array}$ & $\begin{array}{l}15.3 \\
14.6\end{array}$ & $\begin{array}{l}56.6 \\
46.2\end{array}$ & $\begin{array}{l}0.65 \\
0.54\end{array}$ & $\begin{array}{l}1.10 \\
0.81\end{array}$ & 0.11 & 0.49 & 0.288 & 0.118 & 0.594 \\
\hline
\end{tabular}

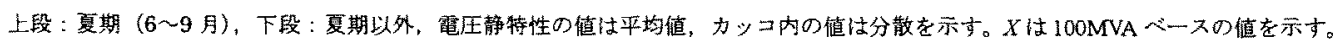

た。この傾向をさらに詳しく分析するため，Kpr，Kgr と気 温 $t{ }^{\circ} \mathrm{C} C$ をプロットした一例を図 8 に示す。

これより，夏期の Kpr，Kqr は気温が高くなるはど，夏期 以外のそれらは気温が低くなるほど小さくなり，Kqr は Kpr に比べて気温感度が高い（気温に対する㑯きが大きい）二 とがわかる。Kq はバラツキが大きいものの，Kpr とともに ある程度気湿に対する相関があることがわかる。この特性 を表現するため，電圧静特性と気温との一次回帰直線（以 下，気温回帰式）を求め, $K p r ， K q r$ と気温回帰式との残差 の分散を表 3 に示す。また, 気温回帰式を図 8 に併記する。

表 3 より，気温回帰式の残差の分散は，表 2 における Kpr， $K q r$ 平均值の分散に比べ全体的に小さいことがわかる。こ れより，電圧静特性の値としては，気温回帰式による推定 值の方が概ね精度のよいことがわかる。

$\langle 4 \cdot 2 \cdot 3\rangle$ 送電線による違い 表 3 と図 8 上り, 各送 電線で気温特性が異なることがわかる。これは各送電線に 接続される負荷機器の構成の違いによるものと思われる。

\section{5. 電圧静特性の一般式の算出}

〈5-1〉考え方 各送電線の負荷機器の構成を把握す ることは困難であるため，需要家などの契約電力種別（高 圧, 業務用, 電灯など) から得られる電力種別（工業, 商 業，住宅）をとに，電圧静特性を一般的に表見すること とする。第 4 章に示したとおり，負荷の電圧静特性は気温 と相関があることから，気温特性を持つ電力種別単位の電

\section{表 3 気温回帰式の残差の分散}

Table 3. Dispersion of Residual between the measured exponents and regression equation of temperature.

\begin{tabular}{|c|c|c|c|c|}
\hline \multirow[b]{2}{*}{ 送暼線 } & \multicolumn{2}{|c|}{ 有効能力の特性 } & \multicolumn{2}{|c|}{ 無効電力の特性 } \\
\hline & 気、温回帰式 & 分散 & 気溜回㷌式 & 分散 \\
\hline A1 & $\begin{array}{c}-0.05 t+2.21 \\
1.18 \\
\end{array}$ & $\begin{array}{l}0.009 \\
0.018\end{array}$ & $\begin{array}{l}-0.13 t+5.73 \\
0.04 t+2.98 \\
\end{array}$ & $\begin{array}{l}0.264 \\
0.225 \\
\end{array}$ \\
\hline A2 & $\begin{array}{c}-0.03 t+1.65 \\
1.02\end{array}$ & $\begin{array}{l}0.009 \\
0.025\end{array}$ & $\begin{array}{l}-0.18 t+8.10 \\
0.10 t+3.49\end{array}$ & $\begin{array}{l}0.531 \\
1.075\end{array}$ \\
\hline$A 3$ & $\begin{array}{l}-0.05 t+2.08 \\
0.01 t+1.14 \\
\end{array}$ & $\begin{array}{l}0.010 \\
0.013\end{array}$ & $\begin{array}{l}-0.05 t+4.96 \\
0.14 t+3.72\end{array}$ & $\begin{array}{l}0.418 \\
0.550\end{array}$ \\
\hline B1 & $\begin{array}{l}0.03 t+1.55 \\
0.01 t+1.07\end{array}$ & $\begin{array}{l}0.020 \\
0.029\end{array}$ & $\begin{array}{l}-0.16 t+6.85 \\
0.07 t+3.16\end{array}$ & $\begin{array}{l}0.240 \\
0.368\end{array}$ \\
\hline $\mathrm{B} 2$ & $\begin{array}{c}-0.04 t+1.93 \\
0.01 t+1.09\end{array}$ & $\begin{array}{l}0.011 \\
0.018\end{array}$ & $\begin{array}{l}-0.11 t+5.40 \\
0.09 t+2.85\end{array}$ & $\begin{array}{l}0.156 \\
0.290\end{array}$ \\
\hline B3 & $\begin{array}{c}-0.04 t+1.76 \\
1.05\end{array}$ & $\begin{array}{l}0.048 \\
0.041\end{array}$ & $\begin{array}{l}0.12 t+5.65 \\
0.05 t+3.24\end{array}$ & $\begin{array}{l}0.512 \\
0.920\end{array}$ \\
\hline Cl & $\begin{array}{r}-0.04 t+1.95 \\
0.01 t+1.17 \\
\end{array}$ & $\begin{array}{l}0.014 \\
0.033\end{array}$ & $\begin{array}{l}-0.08 t+5.09 \\
0.03 t+3.24\end{array}$ & $\begin{array}{l}0.216 \\
0.290\end{array}$ \\
\hline $\mathrm{C} 2$ & $\begin{array}{c}-0.03 t+1.56 \\
1.06\end{array}$ & $\begin{array}{l}0.021 \\
0.050\end{array}$ & $\begin{array}{c}-0.11 t+5.15 \\
3.18\end{array}$ & $\begin{array}{l}0.215 \\
0.909\end{array}$ \\
\hline DI & $\begin{array}{l}-0.03 t+1.74 \\
-0.01 t+1.21\end{array}$ & $\begin{array}{l}0.067 \\
0.046\end{array}$ & $\begin{array}{c}-0.04 t+3.70 \\
3.02\end{array}$ & $\begin{array}{l}0.488 \\
0.460\end{array}$ \\
\hline D2 & $\begin{array}{l}-0.05 t+2.03 \\
-0.01 t+1.31\end{array}$ & $\begin{array}{l}0.055 \\
0.034\end{array}$ & $\begin{array}{l}-0.01 t+2.85 \\
.0 .02 t+3.08\end{array}$ & $\begin{array}{l}0.587 \\
0.302\end{array}$ \\
\hline E1 & $\begin{array}{c}-0.03 t+1.62 \\
1.09\end{array}$ & $\begin{array}{l}0.014 \\
0.026\end{array}$ & $\begin{array}{l}-0.05 t+3.74 \\
0.06 t+3.19\end{array}$ & $\begin{array}{l}0.528 \\
0.539\end{array}$ \\
\hline
\end{tabular}

上段：夏期（6〜9月）、下段：夏期以外 $t:$ 気温 $\left[{ }^{\circ} \mathrm{C}\right]$ 

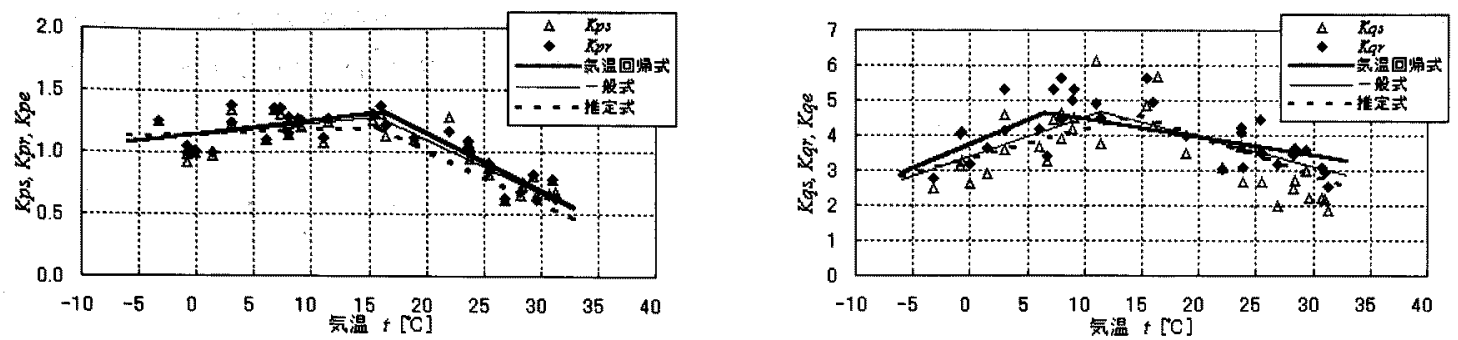

(a) A3 線
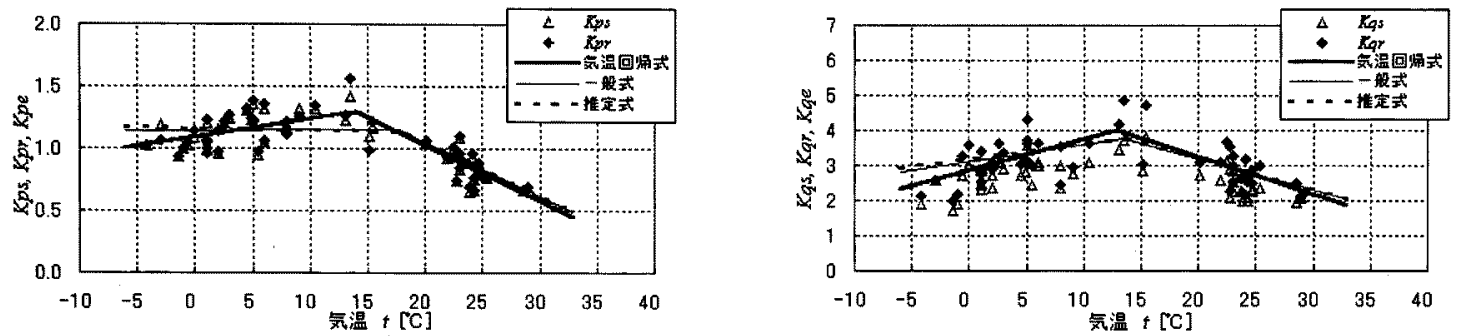

(b) B2 楾
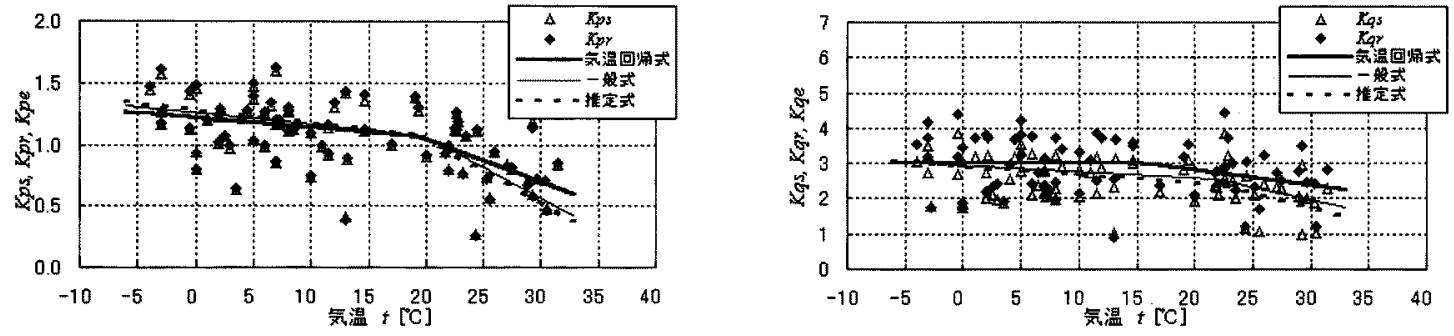

（c）D1 線

気温回㷌式は，Kpr，Kgr と気温 $t$ との一次回帰直線（季節每に算出）。一般式，推定式は後述する。

図 8 電王静特性の気温相関

Fig. 8. Correlation between the exponents of voltage and temperature.

圧静特性 $K p_{i}$ を算出し，これらと電力種別構成比 $P_{i}$ を用い て電圧静特性を一般的に表現する方法を提案する。これに より，非計測点の負荷の電圧静特性についても推定が可能 となる。

〈5·2〉 電圧静特性の一般式の算出方法 Kpr, Kqr は， (11), (13)式に示方気温 $t\left[{ }^{\circ} \mathrm{C}\right]$ と一次相関をもつ電力種別単位 の $K p_{i}, K q_{i}$ が電力種別構成比 $P_{i}$ の加重平均值で表現できる と仮定し，(12)，(14)式の最小二乗法を用いて係数 $a_{p i}, b_{p i}$, $a_{q r}, b_{q i}$ を求める。なお, 季節間 (夏期, 夏期以外) で気温 特性が異なることから，季節毎に係数を求め，その交点で 気温特性が切替わる折線表現とした。

$$
\begin{aligned}
& K p e=\sum_{i=1}^{3} K p_{i} \cdot P_{i} \\
& \text { ここで, } K p_{i}=a_{p i} \cdot t+b_{p i}, \quad \sum_{i=1}^{3} P_{i}=1 \\
& F p=\sum_{j=1}^{N} W p_{j} \cdot\left\{\sum_{i=1}^{3}\left(a_{p i} \cdot t_{j}+b_{p i}\right) \cdot P_{i j}-K p r_{j}\right\}^{2} \rightarrow \text { 最小 }
\end{aligned}
$$

$$
\begin{aligned}
& K q e=\frac{\sum_{i=1}^{3} K q_{i} \cdot Q_{i}}{\sum_{i=1}^{3} Q_{i}}=\frac{\sum_{i=1}^{3} K q_{i} \cdot P_{i} \cdot \tan \theta_{i}}{\tan \theta e} \\
& \text { ここで, } K q_{i}=a_{q i} \cdot t+b_{q i}, \quad \tan \theta e=\sum_{i=1}^{3}\left(P_{i} \cdot \tan \theta_{i}\right) \\
& F q=\sum_{j=1}^{N} W q_{j} \cdot\left\{\sum_{i=1}^{3}\left(a_{q i} \cdot t_{j}+b_{q i}\right) \cdot P_{i j} \cdot \tan \theta_{i}-K q r_{j} \cdot \tan \theta e\right\}^{2} \\
& \rightarrow \text { 最小 } \\
& F q=\sum_{j=1}^{N} W q_{j} \cdot\left\{\sum_{j=1}^{3}\left(a_{q i} \cdot t_{j}+b_{q i}\right) \cdot P_{i j}-K q r_{j}\right\}^{2} \rightarrow \text { 最小 }
\end{aligned}
$$

$K p e, K q e:$ 電圧静特性の一般式

$\tan \theta e: \tan \theta_{i}$ の $P_{i}$ による加重平均値

$N$ : 使用する全ての送電線におけるデータ総数

この際，送電線によるデータ数や Kpr, Kqr のバラッキの 違いを考慮できるよう，重み保数 $W p_{j}, W q_{j}$ を用いた。今回， $W p j, W q_{j}$ は, 気温相関の強い $K p r, K q r$ を重視するように, 気温回帰式の残差の分散の逆数（付録 3 ）としている。また， 
電力種別単位の $\tan \theta$ ，は不明であることから、これをすべて 同值 $\left(\tan \theta_{i}=\tan \theta e\right)$ とした(14)' 式で暼力種別単位の $K q_{i}$ を算出することとした。

〈5-3〉電力種別単位の電圧静特性の特儌 表 4 と 539 個の $K p r ， K q r$ を用いて算出した $K p_{i}, K q_{i}$ を示吉。

\section{表 4 電力種別単位の電压静特性}

Table 4. Load class exponents that are represented as linear equation of temperature.

\begin{tabular}{|c|c|c|c|c|}
\hline 霆力 & \multicolumn{2}{|c|}{ 有効電力 $\sigma$ 特性 } & \multicolumn{2}{|c|}{ 無效電力口特性 } \\
\hline 䅜影 & 夏期以外 & 夏期 & 夏期以年 & 要期 \\
\hline 工嶪 & $0.016 t+0.729$ & $-0.020 t+1.305$ & $0.141 t+3.131$ & $-0.158 t+6.301$ \\
\hline 商業 & $0.083 t+0.866$ & $-0.028 t+1.921$ & $0.620 t+5.427$ & $-0.078 t+11.07$ \\
\hline 住宅 & $-0.023 t+1.388$ & $-0.057 t+2.195$ & $-0.105 t+2.662$ & $-0.061 t+3.190$ \\
\hline
\end{tabular}

$t:$ 気温 $\left[{ }^{\circ} \mathrm{C}\right]$

これより，次のことがすかる。

・工業 $\left(K p_{1}, K q_{1}\right)$ ，商業 $\left(K p_{2}, K q_{2}\right)$ とも，夏期は気温が 高くなるほど，また夏期以外は気温が低くなるほじ小さ くなり，定電力特性に近づく。

・商業は工業よりも気温感度が大きい。

・住宅 $\left(K p_{3}, K q_{3}\right)$ は，工策，商業と比較して年間通じて 気温感度が小さく，夏期・夏期以外とも気温が高くなる ほど小さくなり，定電力特性に近づく。

$\left\langle 5\right.$.4〉 電圧静特性の一般式の算出結果 前節の $K p_{i}$,

\section{表 5 各送電線の電圧静特性の一般式}

Table 5. Linear equations that represent the exponents relation* ship to temperature in 11 measured feeders.

\begin{tabular}{|c|c|c|c|c|}
\hline \multirow[b]{2}{*}{ 总電線 } & \multicolumn{2}{|c|}{ 高效電力の特性 } & \multicolumn{2}{|c|}{ 無効電力の特性 } \\
\hline & 一般式 & 推定式 & 一般式 & 推定式 \\
\hline \multirow{2}{*}{ Al } & $-0.05 t+1.95$ & $-0.04 t+1.82$ & $0.09 t+4.61$ & $-0.07 t+4.20$ \\
\hline & 1.18 & $-0.01 t+1.18$ & $0.021+3.01$ & $0.01 t+3.01$ \\
\hline \multirow{2}{*}{$\mathrm{A} 2$} & $-0.04 t+1.78$ & $-0.04 t+1.79$ & $-0.10 t+5.60$ & $-0.10 t+5.41$ \\
\hline & $0.01 t+1.04$ & $0.01 t+1.04$ & $0.10 t+3.25$ & $0.10 t+3.23$ \\
\hline \multirow{2}{*}{$A 3$} & $-0.04 t+1.96$ & $-0.04 t+1.88$ & $-0.08 t+5.62$ & $-0.11 t+6.29$ \\
\hline & $0.01 t+1.14$ & 1.15 & $0.11 t+3.40$ & $0.08 t+3.33$ \\
\hline \multirow{2}{*}{ B1 } & $-0.04 t+1.81$ & $-0.04 t+1.83$ & $-0.10 t+5.21$ & $-0.09 t+5.03$ \\
\hline & 1.07 & 1.07 & $0.07 t+3.12$ & $0.06 t+3.11$ \\
\hline \multirow{2}{*}{$\mathrm{B} 2$} & $-0.04 t+1.92$ & $-0.04 t+1.93$ & $-0.09 t+4.99$ & $-0.09 t+4.97$ \\
\hline & 1.14 & 1.15 & $0.05 t+3.12$ & $0.04 t+3.17$ \\
\hline \multirow{2}{*}{ B3 } & $.0 .04 t+1.77$ & $-0.04 t+1.77$ & $0.11 t+5.08$ & $=0.10 t+5.04$ \\
\hline & 1.06 & 1.06 & $0.05 t+3.04$ & $0.05 t+3.00$ \\
\hline \multirow{2}{*}{$\mathrm{Cl}$} & $-0.04 t+1.95$ & $-0.04 t+1.94$ & $-0.09 t+5.13$ & $-0.07 t+4.87$ \\
\hline & 1.15 & 1.15 & $0.06 t+3.20$ & $0.07 t+3.20$ \\
\hline \multirow{2}{*}{$\mathrm{C} 2$} & $\cdot 0.03 t+1.64$ & $-0.03 t+1.42$ & $-0.12 t+5.53$ & $-0.24 t+8.57$ \\
\hline & $0.01 t+0.96$ & $0.01 t+0.90$ & $0.09 t+3.10$ & $0.14 t+3.08$ \\
\hline \multirow{2}{*}{ D1 } & $-0.05 t+2.05$ & $-0.05 t+2.12$ & $.0 .08 t+4.21$ & $-0.08 t+4.29$ \\
\hline & $-0.01 t+1.26$ & $-0.01 t+1.27$ & $-0.02 t+2.93$ & $-0.02 t+2.91$ \\
\hline \multirow{2}{*}{$\mathrm{D} 2$} & $-0.05 t+2.09$ & $-0.05 t+2.10$ & $0.07 t+4.44$ & $-0.09 t+5.01$ \\
\hline & $-0.01 t+1.27$ & 1.22 & $0.01 t+3.05$ & $0.05 t+2.96$ \\
\hline \multirow{2}{*}{ E1 } & $.0 .04 t+1.90$ & $-0.04 t+1.91$ & $.0 .09 t+5.01$ & $-0.09 t+5.01$ \\
\hline & 1.14 & 1.14 & $0.05 t+3.12$ & $0.05 t+3.12$ \\
\hline
\end{tabular}

上段：夏期（6〜9月）,下段：夏期以外 $t:$ 気温 $\left[{ }^{\circ} \mathrm{C}\right]$
$K q_{i}$ と各送電線の電力種別構成比 $P_{i}$ から，（11），(13)式によ り送電線每の電圧静特性の一般式を求めることができる。 表 5 に A1〜E1 送電線の一般式を示す。また，二れを図 8 に㐿記する。

$\langle 5 \cdot 4 \cdot 1\rangle$ 電圧静特性の一般式の有効性評価各送電 線において，「気温回帰式による推定值と害測値との相関俰 数 ((15)，(16)式)」と，「一般式に上万推定值と実測值との 相関係数」を比較することにより，一般式の有効性を評価 することとした。表 6 に求めた相関係数を示す。

$$
R p=\frac{\sum_{i=1}^{n}\left(K p r_{i}-A V E(K p r)\right)\left(K p e_{i}-A V E(K p e)\right)}{\sqrt{\sum_{i=1}^{n}\left\{K p r_{i}-A V E(K p r)\right\}^{2} \cdot \sum_{i=1}^{n}\left\{K p e_{i}-A V E(K p e)\right\}^{2}}}
$$

$$
R q=\frac{\sum_{i=1}^{n}\left(K q r_{i}-A V E(K q r)\right)\left(K q e_{i}-A V E(K q e)\right)}{\sqrt{\sum_{i=1}^{n}\left\{K q r_{i}-A V E(K q r)\right\}^{2} \cdot \sum_{i=1}^{n}\left\{K q e_{i}-A V E(K q e)\right\}^{2}}}
$$

$K p r, K q r$ : 実測值 Kpe, Kqe : 推定值

$n$ : 当該送電線における採用デ一夕数

$A V E$ ()は平均值を示す。

\section{表 6 害測值との相関係数}

Table 6. Correlation Coefficient between the mesuered exponents and the estiminated exponents.

\begin{tabular}{|c|c|c|c|c|c|c|}
\hline \multirow{2}{*}{ 送電線 } & \multicolumn{2}{|c|}{$R p$ (有効電力特性の保数) } & \multicolumn{3}{|c|}{$R q$ (無効電力特回饰式性の俰数) } \\
\hline $\mathrm{A} 1$ & 0.895 & 0.889 & 0.884 & 0.758 & 0.744 & 0.727 \\
\hline $\mathrm{A} 2$ & 0.747 & 0.737 & 0.735 & 0.632 & 0.622 & 0.609 \\
\hline $\mathrm{A} 3$ & 0.905 & 0.903 & 0.888 & 0.597 & 0.668 & 0.695 \\
\hline $\mathrm{B} 1$ & 0.750 & 0.745 & 0.742 & 0.746 & 0.716 & 0.711 \\
\hline $\mathrm{B} 2$ & 0.830 & 0.762 & 0.743 & 0.679 & 0.635 & 0.614 \\
\hline $\mathrm{B} 3$ & 0.651 & 0.650 & 0.650 & 0.559 & 0.561 & 0.561 \\
\hline $\mathrm{C} 1$ & 0.811 & 0.809 & 0.809 & 0.656 & 0.618 & 0.625 \\
\hline $\mathrm{C} 2$ & 0.422 & 0.450 & 0.462 & 0.436 & 0.459 & 0.401 \\
\hline $\mathrm{D} 1$ & 0.570 & 0.570 & 0.570 & 0.242 & 0.263 & 0.264 \\
\hline $\mathrm{D} 2$ & 0.754 & 0.746 & 0.717 & 0.338 & 0.270 & 0.160 \\
\hline $\mathrm{E} 1$ & 0.798 & 0.795 & 0.793 & 0.578 & 0.698 & 0.692 \\
\hline
\end{tabular}

これより，一般式は気温回㷌式と同程度の精度であるこ とがかかり，(11)，(13)式が負荷の電圧静特性の推定に有効 であるといえる。なお，D1，D2 線の無效電力特性について は，気温回㷌式の相関係数からわかるように，もともと気 温との相関が低い。

\section{$\langle 5 \cdot 4 \cdot 2\rangle \quad$ 非計測点における推定值の有效性評洒}

般式の非計測点での有効性を確認するため，当該送電線の 実測值が不明と仮定して，その他の送電線の実測值から算 出した $K p_{i} ， K q_{i}$ による一般式（以下，推定式）を求めた。 表 5 に 1 〜 E1 送電線の推定式を併記する。推定式による 


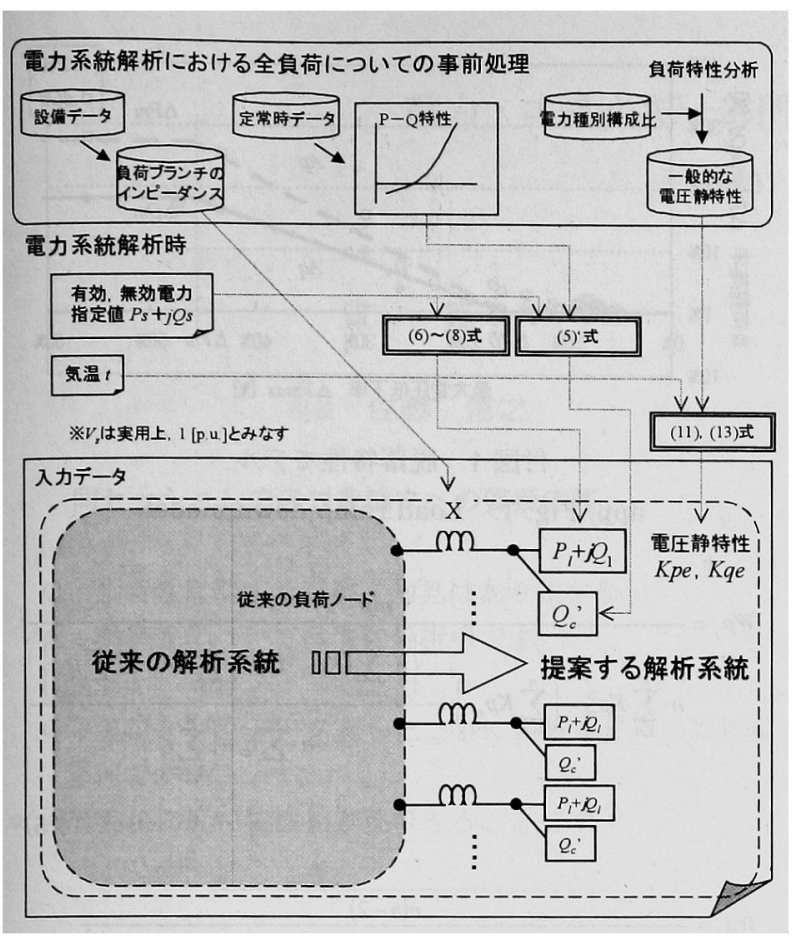

図 9 提案する系統負荷モデルの電力系統解析への適用

Fig. 9. Application of the bus load model we propose to power system simulation.

推定值と実測値との相関係数を求め, 前節と同様に気温回 帰式での相関係数と比較した。表 6 に求めた相関係数を併 記する。

これより, D2 線の無効電力特性を除き, 気温回㷌式と同 程度の精度で電圧静特性が求まることがわかり，一般的な 電圧静特性が非計測点での電圧静特性の推定に有効である といえる。

\section{6. 電力系統解析への適用方法}

図 9 に提案した系統負荷モデルと電圧静特性の推定值の

電力系統解析への適用方法について示す。

事前処理 : 次の 3 つの処理を行っておく。

・設備データから負荷ブランチのインピーダンスを求め る。

・定常時データから $\mathrm{P}-\mathrm{Q}$ 特性を把握する。

・電力種別構成比から電圧静特性の一般式を求める。 電力系統解析時 : 電力系統解析の負荷ノードにおける有効, 無効電力指定值 $P_{s}+j Q_{s}$ [p.u.] 加負荷の $P_{l}+j Q_{l}$ [p.u.], $Q_{c}{ }^{\prime}$ [p.u.]を, 気温 $\left.t{ }^{\circ} \mathrm{C}\right]$ から電圧静特性 $K p e, K q e$ を求め, 入力 データに設定する。

\section{7. まとめ}

本論文を要約すると次のとおりである。

（1）電力系統解析用の負荷の表現方法として, 負荷ブラ ンチ, 無効電力補償量および負荷からなる系統負荷モデル を提案し, 実測データから負荷の電圧静特性 $K p r, K q r$ を算
出した。

（2）非計測点の負荷の電圧静特性を求めるため, 電力種 別構成比と気温で表現される電圧静特性の一般式の算出方 法を提案し，その有効性を示した。

（3）提案した系統負荷モデルと電圧静特性の推定値の電 力系統解析への適用方法を示した。

以上より，従来よりもきめ細かな系統負荷の設定ができ， 電力系統解析の精度向上が期待できる。

今後, 負荷機器の単体特性の把握などにより, 今回求め た電力種別単位の特性に関する定性的な評価を行うととも に，さらなるデータの蓄積と過渡領域での負荷電圧特性把 握（電圧動特性定数，誘導機定数）に関する検討を行う予 定である。

最後に本研究を進めるにあたり，ご指導いただいた（財） 電力中央研究所の浅田実氏, 山下光司氏，熊野照久氏，及 びデータ収集・処理にご協力いただいた（株）近計システ ムの櫻井通氏，(株) 日本オープンシステムズの高山崇氏に 厚く御礼申し上げます。

(平成 14 年 2 月 28 日受付, 平成 14 年 6 月 20 日再受付)

\section{文献}

(1) M. Asada and K. Yamashita : "An Analysis of the present Load Characteristic in Japan 60Hz System", T.IEE Japan, Vol.121-B, No.10, pp.1371-1378 (2001-10) (in Japanese) 浅田 実・山下光司:「わが国 $60 \mathrm{~Hz}$ 采統における負荷特性の実態分 析」, 電学論 B, 121，10, pp.1371-1378 (2001-10)

(2) C.Concordia and S.Ihara : "Load Representation in Power System Stability Studies", IEEE Trans. Power Apparatus \& Syst., 8 PAS-101, No.4, pp.969-977 (1982-4)

(3) IEEE Task Force on Load Representation for Dynamic Perform ance : "Load Representation for Dynamic Performance Analysis", IEEE Tras. Power Syst., 8, No.2, pp.472-482 (1993-5)

(4) M.Bonstancy, J.Koplowitz, and C.W.Taylor : "Identification of Power System Load Dynamics Using Artificical Neural Networks", IEEE Tras. Power Syst., 12, No.4, pp.1468-1473 (1997-11)

(5) M. Asada, K. Yamashita, and S. Hosoki : "A Study on the Load Voltage and Frequency Characteristics of Electric Appliances", PSE-99-37 (1999) (in Japanese)

浅田 実・山下光司・細木 訓:「負荷機器の電圧および周波数特性 に関する検討」, 電気学会電力系統技術研究会, PSE-99-37 (1999)

(6) K.Tomiyama : "Estimation of Voltage Sensitivity of Bus Load for Power System Analysis", T.IEE Japan, Vol.119-B, No.3, pp.326-332 (1999-3) (in Japanese) 富山勝幸: 「系統解析のための静的負荷特性の推定手法」, 電学諭 B 119，3，pp.326-332 (1999-3)

(7) M.Fauri : "Harmonic Modelling of Non-Linear Load by means of Crossed Frequency Admittance Matrix", IEEE Tras.Power Syst., 12, No.4, pp.1632-1638 (1997-11)

(8) Y. Nakao, M. Sato, and N. Nakazama : "Measurement and Analysis of Power System Load Characteristic Using P-Q Correlation", 1995 National Convention Record, IEE Japan, No.1313 (1995) (in Japanese) 中尾勇一・佐藤正昭・中澤元丸：「P-Q 相関を用いた系統負荷特性定 数の測定と分析」, 平成 7 年電気学会全国大会, No.1313 (1995)

(9) G. J. Berg : "Power-system load representation", Proc. IEE, 120, No.3, pp.344-348 (1973-3)

（10）長尾待士 - 浅田実 - 内田直之 - 氏原悦雄 - 杉浦徳廣 - 鈴木邦夫 : 「大 幅電圧変動時の電力系統の負荷特性 その 1 2 1 , 電中研報告, 183523 (1984), 183524 (1986) 
付録

1. 電圧静特性に対するリアクタンスの影響

送受電端の電圧静特性の関倸式は次のように表される(9)。

$$
\begin{array}{r}
K p s=K p r \cdot \frac{1+\frac{X \cdot Q_{l}}{V_{r}^{2}}+\frac{X^{2} \cdot P_{l}^{2}}{2 V_{r}^{4}}}{1+\frac{X \cdot Q_{l}}{V_{r}^{2}}(K q r-1)+\frac{X^{2} \cdot P_{l}^{2}}{2 V_{r}^{4}}(2 K p r-3)} \\
K q s=K q r \cdot \frac{1+\frac{X \cdot Q_{l}}{V_{r}^{2}}+\frac{X^{2} \cdot P_{l}^{2}}{2 V_{r}^{4}}}{1+\frac{X \cdot Q_{l}}{V_{r}^{2}}(K q r-1)+\frac{X^{2} \cdot P_{l}^{2}}{2 V_{r}^{4}}(2 K p r-3)} \\
\quad \times \frac{1+\frac{2 X \cdot Q_{l}}{V_{r}^{2}}\left\{\frac{K q r-1}{K q r}+\left(\frac{P_{l}}{Q_{l}}\right)^{2} \cdot \frac{K p r-1}{K q r}\right\}}{1+\frac{X \cdot Q_{l}}{V_{r}^{2}}\left\{1+\left(\frac{P_{l}}{Q_{l}}\right)^{2}\right\}}
\end{array}
$$

\section{2. 負荷脱落特性モデル(10)}

負荷の脱落特性は, 系統故障などの瞬時電圧低下による 最大電圧低下率 $\Delta V_{\max }$ が， $\Delta V_{0}$ 以上となると負荷脱落が発 生し， $\Delta V_{\mathrm{m}}$ 以上となると脱落負荷量は飽和するといった特 性を概ね示していることから, 付図 1 のような折線で模擬 することとする。

$$
\begin{aligned}
& \Delta V_{\max }=\frac{V_{r i}-V_{\min }}{V_{r i}} \\
& 0 \leq \Delta V_{\max }<\Delta V_{0} \text { のとき }, \quad \Delta P d=0 \\
& \Delta Q d=0 \\
& \Delta V_{0} \leq \Delta V_{\max }<\Delta V_{m} \text { のとき， } \\
& \Delta P d=A p\left(\Delta V_{\max }-\Delta V_{0}\right) \\
& \Delta Q d=A q\left(\Delta V_{\max }-\Delta V_{0}\right) \\
& \text { ただし, } A p=\frac{\Delta P_{m}}{\Delta V_{m}-\Delta V_{0}}, \quad A q=\frac{\Delta Q_{m}}{\Delta V_{m}-\Delta V_{0}} \\
& \Delta V_{\max } \geq \Delta V_{m} \text { のとき, } \quad \Delta P d=\Delta P_{m} \\
& \Delta Q d=\Delta Q_{m}
\end{aligned}
$$

$\Delta V_{\max }:$ 最大電圧低下率

$V_{\min }:$ 最低電圧値

$\Delta P d, \Delta Q d:$ 有効, 無効電力の負荷脱落率

$\Delta V_{0}:$ 脱落開始電圧低下率

$\Delta V_{m}:$ 脱落飽和電圧低下率

$\Delta P_{m}, \Delta Q_{m}:$ 有効, 無効電力の脱落上限率

$A p, A q$ : 有効, 無効電力の脱落増加率

\section{3. 重み係数}

今回重み係数 $W p_{j}, W q_{j}$ は(付 5 )，(付 6)式のように与える こととする。

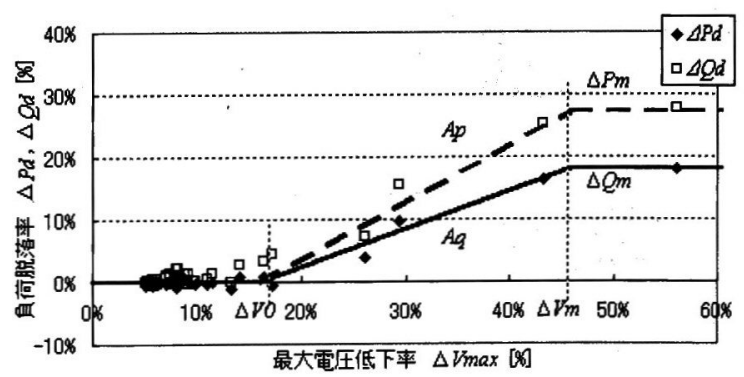

付図 1 脱落特性モデル

app. Fig. 1. Load ramp down model.

$$
W p_{j}=\frac{n(n-2)}{n \cdot \sum_{k=1}^{n} K p_{r k}^{2}-\left(\sum_{k=1}^{n} K p_{r k}\right)^{2}-\frac{\left\{n \cdot \sum_{k=1}^{n}\left(K p_{r k} \cdot t_{k}\right)-\left(\sum_{k=1}^{n} K p_{r k}\right) \cdot\left(\sum_{k=1}^{n} t_{k}\right)\right\}^{2}}{n \cdot \sum_{k=1}^{n} t_{k}^{2}-\left(\sum_{k=1}^{n} t_{k}\right)^{2}}}
$$

$$
W q_{j}=\frac{n(n-2)}{n \cdot \sum_{k=1}^{n} K q_{k}^{2}-\left(\sum_{k=1}^{n} K q_{k_{k}}\right)^{2}-\frac{\left\{n \cdot \sum_{k=1}^{n}\left(K q_{k *} \cdot t_{k}\right)-\left(\sum_{k=1}^{n} K q_{k k}\right) \cdot\left(\sum_{k=1}^{n} t_{k}\right)\right\}^{2}}{n \cdot \sum_{k=1}^{n} t_{k}^{2}-\left(\sum_{k=1}^{n} t_{k^{\prime}}\right)^{2}}}
$$

$n:$ 当該送電線における採用データ数

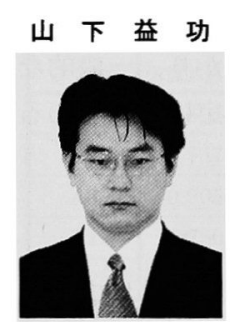

（正員） 1972 年 8 月 10 日生。1995 年 3 月上 智大学理工学部電気電子工学科卒業。同年 4 月 北陸電力惏入社。現在, 技術開発研究所に勤務。 主として, 電力系統解析に関する研究に従事。

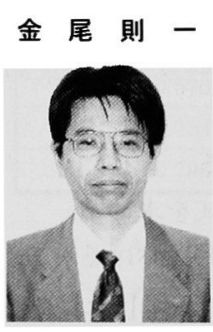

（正員） 1959 年 9 月 19 日生。1984年 3 月名 古屋大学大学院工学研究科電気工学専攻修士 課程修了。同年 4 月北陸電力(㑿入社。現在, 技 術開発研究所に勤務。同所副課長。主として, 電力系統解析に関寸る研究に従事。

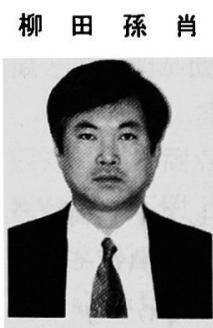

（正員） 1957 年 10 月 12 日生。 1981 年 3 月早 稲田大学理工学部電気工学科卒業。同年 4 月北 陸電力俶入社。平成 10 年から技術開発研究所 に勤務。現在, 石川総合制御所所長。主として, 電力系統解析・運用に関する業務に従事。 
電力・エネルギー部門大会座長のコメントと回答

-A20 解析技術(2)-

\section{質 疑}

\section{座長 佐藤 信之}

\section{1. 同セッションでの対象論文への質疑応答}

(1)

$\mathrm{Q}$ ：動特性に関する考察・知見はありますか。

A：動特性については現在分析中です。

(2)

$\mathrm{Q}$ : 気温をパラメータとしたことによるモデル上の利点は 何ですか?

A：実状に近い特性を表現できることです。

\section{応答}

山下 益功・金尾 則一

柳田 孫肖

(北陸電力)

\section{1.「同セッションでの質疑応答」に対する追加説明}

(1)kついての追加説明

今回算出した負荷の電圧動特性および時定数につき ましては, 気温などとの相関はみられませんでした。 負荷の動特性は，主に誘導機やインバー夕負荷に起因
するものと考えられます。これらの負荷は系統故障時 の電圧低下量や継続時間により，電圧動特性や時定数 の值が変化します。また，誘導機の多く含む負荷の母 線に招いては, 系統故障除去後の電圧の回復が困難に なる場合があり，この現象は(9)，(10)式で示される一 次遅れモデルでは表現することができません。したが いまして，負荷の動特性については，誘遒機を含む負 荷モデルに関する検討を行っております。

（2）についての追加説明

図 8 に示すように, 電圧静特性は気温と相関がある ことを確認できました。これはエアコンなどの泠暖房 機器の稼動に関連があることが示唆されます。表 3 か ら電圧静特性の季節別の平均值よりも, 気温の一次式 （論文では「気温回帰式」）で推定した値のほうが，お おむ站実測値との残差分散が小さいため，代表值（電 力系統解析で設定する負荷の電圧静特性の值）上して 適していると判断しました。以上より, 需要家単位の 負荷機器の構成比や使用状態を細かく調查しなくて も, 気温をパラメータとすることにより, 負荷機器の 季節的な変化を反映した電圧静特性を推定できるもの と考えております。この結果，電圧静特性を季節別に 設定した電力系統解析により系統運用容量（安定度, 電圧）を算出すれば，季節別管理による柔軟な系統運 用も期待できるものと考えられます。 